\title{
A new species and two new combinations of Monolophus (Zingiberaceae) from Indo-Burma
}

\author{
Hong-Bo Ding', Bin Yang',2, Mya Bhone Maw', Pyae Pyae Win³, Yun-Hong Tan ${ }^{1,2}$ \\ I Southeast Asia Biodiversity Research Institute, Chinese Academy of Sciences \& Center for Integrative Conser- \\ vation, Xishuangbanna Tropical Botanical Garden, Chinese Academy of Sciences, Menglun, Mengla, Yunnan \\ 666303, China 2 Center of Conservation Biology, Core Botanical Gardens, Chinese Academy of Sciences, \\ Menglun, Mengla, Yunnan 666303, China 3 Forest Research Institute, Forest Department, Ministry of Envi- \\ ronmental Conservation and Forestry, Yezin, Nay Pyi Taw 05282, Myanmar
}

Corresponding author: Yun-Hong Tan (tyh@xtbg.org.cn)

Academic editor:Xiao-Hua Jin | Received 18 August 2019 | Accepted 27 November 2019 | Published 10 January 2020

Citation: Ding H-B, Yang B, Maw MB, Win PP, Tan Y-H (2020) A new species and two new combinations of Monolophus (Zingiberaceae) from Indo-Burma. In: Jin X-H, Xia N-H, Tan Y-H (Eds) Plant diversity of Southeast Asia-II. PhytoKeys 138: 155-162. https://doi.org/10.3897/phytokeys.138.39217

\begin{abstract}
Monolophus odontochilus Y.H.Tan \& H.B.Ding, a new species from Northern Myanmar, is described and illustrated. The new species is morphologically similar to $M$. linearis, but differs by having elliptic to oblong leaves (vs. linear-lanceolate to lanceolate), bilobed ligules (vs. entire), purely white corolla (vs. pinkish white), semi-orbicular crenate labellum (vs. trilobed). In addition, a diagnostic key to the new species of Monolophus and its closely related non-yellow flowered species is provided. New combinations are proposed here for Caulokaempferia phokhamii Picheans. \& Douangde. and C. wongsuwaniae Picheans. $\&$ Douangde. from Laos.
\end{abstract}

\section{Keywords}

Caulokaempferia phokhamii, Caulokaempferia wongsuwaniae, Kachin State, Putao District

\section{Introduction}

The genus Monolophus was first described by Wallich (1832) and included three species with references to earlier publications in 1820, 1829; and was recognised by Endlicher (1837), followed by Steudel (1841), Horaninov (1862), Pfeiffer (1874), Wu and

Copyright Hong-Bo Ding et al. This is an open access article distributed under the terms of the Creative Commons Attribution License (CC BY 4.0), which permits unrestricted use, distribution, and reproduction in any medium, provided the original author and source are credited. 
Chen (1978). But for a very long time it was treated under Caulokaempferia K. Larsen (1964). Recently, the genus Monolophus was reinstated by Mood et al. (2014) with 22 new combinations. So far, the genus consists of 33 species (Larsen and Smith 1972; Larsen 1973, 2002; Larsen et al. 2004; Larsen and Jenjittikul 2004; Suksathan and Triboun 2004; Picheansoonthon and Mokkamul 2006; Ngamriabsakul 2008; Picheansoonthon et al. 2008; Picheansoonthon and Koonterm 2008; Tiyaworanant 2010; Chaturvedi et al. 2012; Roy and Barbhuiya 2013; Intharapichai et al. 2014; Mood et al. 2014; Phokham et al. 2015a, b; Sangnark et al. 2016; Veldkamp 2016; Bhaumik et al. 2017; Barbhuiya et al. 2018; Douangdeuane et al. 2019) from the Himalayas to South East Asia. There are two distinct groups, the yellow-flowered species ( -28 taxa) that are distributed in Thailand and adjacent countries and the other non-yellowflowered species (purple, red-purple, pink and white) ( -5 taxa) which are localized in Eastern Himalaya (Bhaumik et al. 2017).

During our field work from May to June in 2018, some interesting specimens of Monolophus were found in Putao, Kachin state. Based on the detailed examination of the morphological characters of our material and morphologically similar species, we draw a conclusion that those specimens of Monolophus collected in Myanmar belong to a species new to science, Monolophus odontochilus Y.H.Tan \& H.B.Ding, which is described here along with illustrations.

\section{Material and methods}

Measurements and morphological character assessments of the new species have been examined based on fresh materials and dried specimens. It has been compared with the morphologically similar species by affinities inferred using descriptions (Wallich 1820, 1832; Chaturvedi et al. 2012; Roy and Barbhuiya 2013) and type specimens in herbaria $(\mathrm{K}, \mathrm{L}, \mathrm{E})$. Protologues and images of type specimens and dried herbarium specimens were gathered from JSTOR Global Plants (http://plants.jstor.org).

\section{Taxonomic treatment}

Monolophus odontochilus Y.H.Tan \& H.B.Ding, sp. nov. urn:Isid:ipni.org:names:77204203-1

Figure 1

Diagnosis. Monolophus odontochilus is morphologically similar to M. linearis (Wall.) Wall. from India in having white flowers with yellow blotch at the base of the labellum, but differs by having elliptic to oblong leaves (vs. linear-lanceolate to lanceolate leaves), bilobed ligules (vs. entire ligules), semi-orbicular crenate labellum (vs. trilobed labellum) and purely white corolla (vs. pinkish white corolla). 


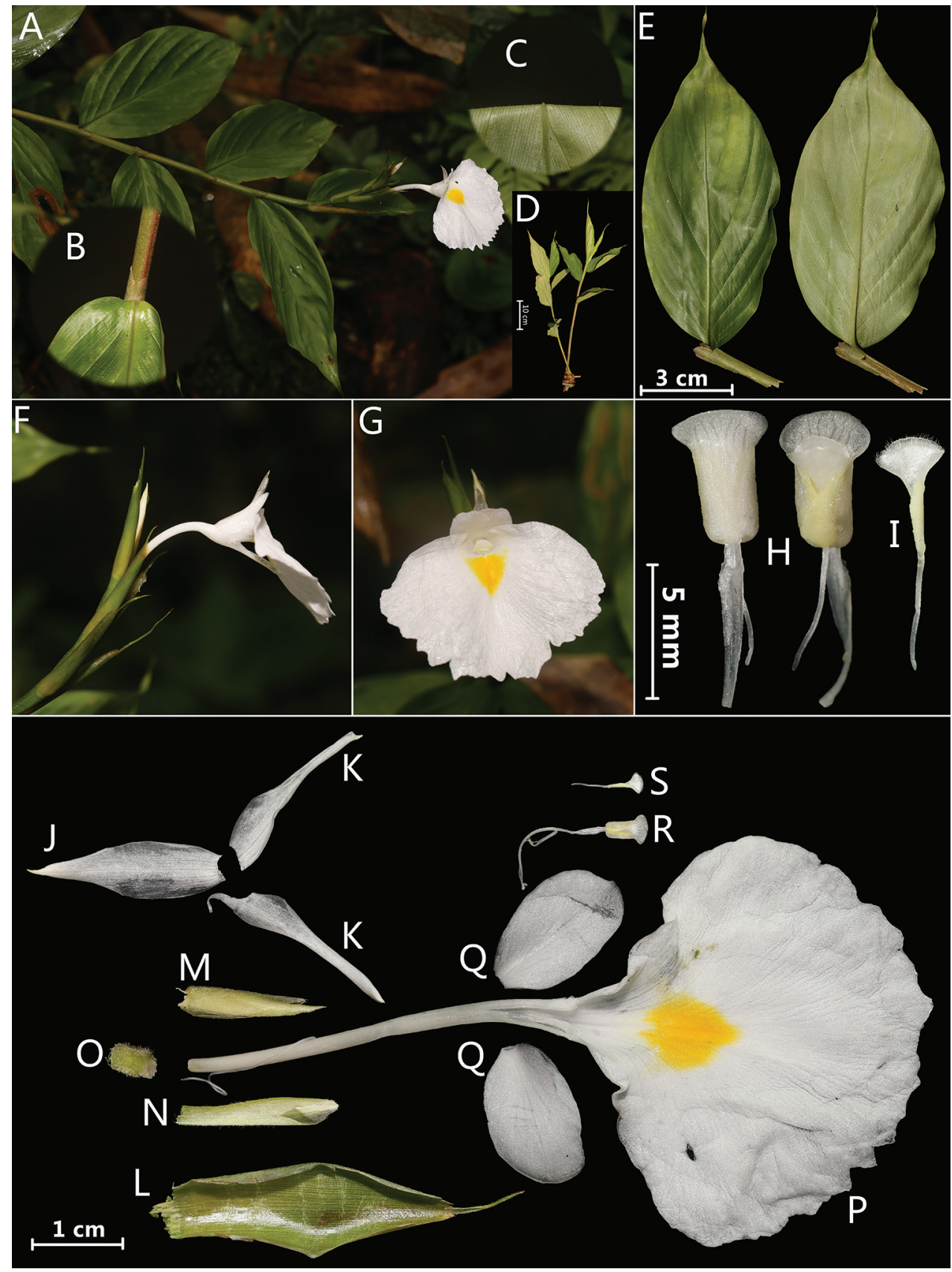

Figure I. Monolophus odontochilus Y.H. Tan \& H.B. Ding, sp. nov. A habitat B ligule C leaf blade abaxially $\mathbf{D}$ habit $\mathbf{E}$ single leaf (adaxially and abaxially) $\mathbf{F}$ flower (side view) $\mathbf{G}$ flower (front view) $\mathbf{H}$ anther with stigma and crest (front and back view) I stigma J dorsal corolla lobe $\mathbf{K}$ lateral corolla lobes $\mathbf{L}$ bracts $\mathbf{M}$ bracteoles and young flower $\mathbf{N}$ calyx $\mathbf{O}$ ovary $\mathbf{P}$ labellum and floral tube $\mathbf{Q}$ lateral staminodes $\mathbf{R}$ stamen and stigma $\mathbf{S}$ ovary with style. Photographed by H.B.Ding 
Type. Myanmar. Kachin State: Putao District, Gathu Village. $27^{\circ} 29^{\prime} 07.23$ "N, 97'58'19.49"E, 643 m, 01 June 2018, Y.H.Tan, B.Yang, H.B.Ding, X.D.Zeng, M.B.Maw and H.L.Neing M3886 (holotype: HITBC!, isotypes: RAF!).

Description. Perennial herbs, rhizome short; pseudostem erect, leafy $50-70 \mathrm{~cm}$ long. Leaves 5-13, sub-sessile, elliptic to oblong, 10.2-14 × 3.0-5.0 cm, base cuneate, apex caudate to $2.0 \mathrm{~cm}$ long, margins entire, adaxial surface dark green, glabrous, abaxially light green, pubescent; ligule membranous, 6-8 mm long, hairy, apex unequally bilobed. Inflorescences terminal, 5-7 cm long, rachis glabrous; flowers white with yellow blotch at the base of the labellum; bracts 4-6, along rachis, distichous, oblong, 3.5-4.0 $\times 1.0-1.3 \mathrm{~cm}$, greenish, outer surface pubescent, base truncate, apex cuspidate to $0.8 \mathrm{~cm}, 2$-flowered; bracteoles membranous, lanceolate, ca. $1.5 \times 0.8 \mathrm{~cm}$, pubescent, rounded; calyx tubular, 1.3-1.4 $\times 0.3-0.4 \mathrm{~cm}$, pubescent, greenish, split 6-7 mm down one side, apex acute; floral tube $4.3-4.5 \mathrm{~cm}$, ca. $3.5 \mathrm{~mm}$ wide at mouth, white, glabrous; dorsal corolla lobe lanceolate, $2.2-2.3 \times 0.6-0.7 \mathrm{~cm}$, white, glabrous, hooded at apex, apical cusp ca. $2 \mathrm{~mm}$ long; lateral corolla lobes similar to dorsal lobe, narrower, $2.0-2.1 \times 0.3-0.4 \mathrm{~cm}$, hooded at apex, apical cusp ca. $1 \mathrm{~mm}$ long; lateral staminodes elliptic, $1.5-1.6 \times 0.9-1.0 \mathrm{~cm}$, white, apex rounded; labellum semi-orbicular, 4.4-4.8 $\times 3.2-3.6 \mathrm{~cm}$, white with yellow spot at base, margin crenate; anther 4-5 $\mathrm{mm}$ long; anther crest flabellate, 2-3 $\times 4-5 \mathrm{~mm}$, white, apex entire; stigma funnel-shaped, inserted between anther sac, margin raised on both ends, ciliate; ovary oblong, 3-4 mm long, pubescent, 3-locular.

Phenology. Flowering in May to June. Fruit not seen.

Etymology. The species epithet 'odontochilus' refers to the crenate labellum.

Distribution and habitat. Monolophus odontochilus is endemic to Kachin State, Northern Myanmar, only known from its type locality, Gathu Village, Putao District. It grows in humid environments or along streams of tropical rain forest at an elevation of $550-750 \mathrm{~m}$.

Conservation status. This new species appears to be restricted to a very moist habitat in Gathu Village, Putao District, Kachin State, Northern Myanmar. According to our observations in the field, the two known populations are composed of about 50 mature individuals in each. Overall, however, the species has been deemed to be Data Deficient (DD) following IUCN Red list Categories and Criteria (IUCN 2017). Further field surveys in northern Myanmar are needed to gain more information on its distribution.

Affinities. Monolophus odontochilus is morphologically similar to M. linearis (Wall.) Wall. (Wallich 1820, 1832) in having white flowers with a yellow blotch at the base of the labellum. After comparison with specimens and descriptions in literature (Chaturvedi et al. 2012; Roy and Barbhuiya 2013), it was found that $M$. odontochilus can be distinguished from $M$. linearis, even on the basis of its vegetative characters: e.g. Monolophus odontochilus has unequally bilobed ligule (vs. entire ligule, respectively), longer calyx $(1.3-1.4 \mathrm{~cm}$ vs. $0.8-0.9 \mathrm{~cm}$, respectively), bigger lateral staminodes $(1.5-1.6 \times$ $0.9-1.0 \mathrm{~cm}$ vs. ca. $1.0 \times 0.7 \mathrm{~cm}$, respectively). Monolophus odontochilus, furthermore, 
differs in having elliptic to oblong leaves $(10.2-14 \times 3-5 \mathrm{~cm})$, margin crenate labellum (non-trilobed) and purely white corolla. Monolophu linearis has linear lanceolate leaves $(1.5-6.5 \times 0.5-1 \mathrm{~cm})$, trilobed labellum and pinkish white corolla. A diagnostic key to the new species of Monolophus and its closely related species is provided.

A diagnostic key to the non-yellow flowered of Monolophus is given below

$1 \quad$ Flowers completely pink

- $\quad$ Flowers usually white, if corolla and lateral staminodes pink then labellum white 3

All leaves sessile, blade to $2.8 \mathrm{~cm}$ broad, ligule absent or indistinct

M. suksathanii

- $\quad$ At least upper leaves petiolate, blade $2.5-4 \mathrm{~cm}$ broad, ligule distinct

M. secundus

3 Labellum completely white, without yellow blotch M. sikkimensis

- $\quad$ Labellum white with yellow blotch 4

4 Corolla completely white M. odontochilus Corolla pink to purple-pink. 5

M. arunachalensis

\section{New combinations}

Mood et al. (2014) have argued that the generic name Caulokaempferia is a superfluous name of genus Monolophus. A proposal to conserve Caulokaempferia by Intharapichai et al. (2014) has not yet been considered by the appropriate committee. Therefore, in our opinion, Monolophus is valid and the name Caulokaempferia must be rejected. Recently, Douangdeuane et al. (2019) described two new species under Caulokaempferia from Laos, which are transferred here to Monolophus.

Monolophus phokhamii (Picheans. \& Douangde.) Y.H.Tan \& H.B.Ding, comb. nov. urn:Isid:ipni.org:names:77204204-1

Basionym. Caulokaempferia phokhamii Picheans. \& Douangde. in Douangdeuane et al., Pak. J. Bot. 51(1): 235. 2019.

Type. Lao PDR. Vientiane Province, Hin Herb District, Phou Meut-Phou Kiykon Forest Conservation, Ban Hoiuy Dokmai (Hoiuy Dokmai Waterfall), $18^{\circ} 42^{\prime} 58.20^{\prime \prime N}, 102^{\circ} 22^{\prime} 20.94^{\prime E}, 270$ m, 26 August 2014, CP260814-1 (holotype: $\mathrm{BK}$, isotypes: MSU). 


\section{Monolophus wongsuwaniae (Picheans. \& Douangde.) Y.H.Tan \& H.B.Ding, comb. nov. \\ urn:lsid:ipni.org:names:77204205-1}

Basionym. Caulokaempferia wongsuwaniae Picheans. \& Douangde. in Douangdeuane et al., Pak. J. Bot. 51(1): 237. 2019.

Type. Lao PDR. Bolikhamxai Province, Mueang Tha Pabad District, Nam Tok Tad Mangkorn, 18²5'59.82"N, 103²'32.64"E, 200 m, 20 September 2014, CP200914-1 (holotype: BK, isotypes: MSU).

\section{Acknowledgements}

The authors are grateful to the Forest Research Institute of Myanmar for permission to conduct this study in the Northern Myanmar, and for their support and collaboration. We are grateful to Xiao-Dong Zeng, Kyaw Saw and Myint Zaw for their kind help in the fieldwork. This work was financially supported by a grant from National Natural Science Foundation of China (Grant no. 31970223) awarded to Yun-Hong Tan, by a project of the Lancang-Mekong Cooperation (LMC) Special Fund (Biodiversity Monitoring and Network Construction along Lancang-Mekong River Basin project), by the Southeast Asia biodiversity research institute, Chinese Academy of Sciences (Y4ZK111B01) and the CAS 135 program (No. 2017XTBG-F03).

\section{References}

Barbhuiya HA, Dey S, Verma D, Moaakum (2018) Nomenclatural notes on some taxa of Monolophus (Zingiberaceae). NeBio 9(2): 175-176.

Bhaumik M, Langhu T, Dey S, Deb CR, Jamir NS (2017) Two new species of Monolophus (Zingiberaceae) from India. Kew Bulletin 72: 1-6. https://doi.org/10.1007/s12225-017-9687-4

Chaturvedi SK, Sinha BK, Dey S, Roy DK, Pandey S (2012) Notes on Caulokaempferia linearis (Wallich) K. Larsen - a rare ginger of India. Pleione 6(2): 420-424.

Douangdeuane B, Phokham B, Wongsuwan P, Picheansoonthon C (2019) The genus Caulokaempferia K. Larsen (Zingiberaceae) in Lao PDR part 1: Two new species from central Lao PDR. Pakistan Journal of Botany 51(1): 235-240. https://doi.org/10.30848/ PJB2019-1(23)

Endlicher S (1837) Zingiberaceae. Genera Plantarum. Beck, Vienna, 221-225.

Horaninov PF (1862) Prodromus Monographiae Scitaminearum. Academia Caesareae Scientiarum, St. Petersburg, 45 pp.

Intharapichai K, Phokham B, Wongsuwan P, Picheansoonthon C (2014) The genus Caulokaempferia (Zingiberaceae) in Vietnam. Shokubutsu Kenkyu Zasshi 89: 129-136.

Larsen K (1964) Studies in Zingiberaceae IV. Caulokaempferia, a new genus. Botanisk Tidsskrift 60: 165-179. 
Larsen K (1973) Studies in Zingiberaceae VI. Botanisk Tidsskrift 68: 157-159. https://doi. org/10.1086/365973

Larsen K (2002) Three new species of Caulokaempferia (Zingiberaceae) from Thailand with a discussion of the generic diversity. Nordic Journal of Botany 22(4): 409-417. https://doi. org/10.1111/j.1756-1051.2002.tb01392.x

Larsen K, Jenjittikul T (2004) A new species of Caulokaempferia (Zingiberaceae) from Laos. Edinburgh Journal of Botany 60(3): 509-512. https://doi.org/10.1017/S0960428603000374

Larsen K, Smith RM (1972) Notes on Caulokaempferia. Notes from the Royal Botanic Garden Edinburgh 31: 287-295.

Larsen K, Suksathan P, Triboun P (2004) Further studies in the genus Caulokaempferia (Zingiberaceae) in Thailand with the description of two new species. Nordic Journal of Botany 23(4): 401-416. https://doi.org/10.1111/j.1756-1051.2003.tb00412.x

Mood JD, Veldkamp JF, Dey S, Prince LM (2014) Nomenclatural changes in Zingiberaceae: Caulokaempferia is a superfluous name for Monolophus and Jirawongsea is reduced to Boesenbergia. Gardens' Bulletin (Singapore) 66(2): 215-231.

Ngamriabsakul C (2008) Caulokaempferia sirirugsae sp. nov. (Zingiberaceae) from southern Thailand. Nordic Journal of Botany 26(5-6): 325-328. https://doi.org/10.1111/j.17561051.2008.00328.x

Pfeiffer L (1874) Monolophus. Nomenclator Botanicus. Fischer, Cassel, 348 pp.

Phokham B, Prasarn S, Sangnark S, Wongsuwan P (2015a) A new species of Caulokaempferia (Zingiberaceae) from Western Thailand. Shokubutsu Kenkyu Zasshi 90: 153-157.

Phokham B, Intharapichai K, Wongsuwan P, Picheansoonthon C (2015b) Caulokaempferia pubescens (Zingiberaceae) - a new species from Northern Thailand. Taiwania 60(2): 77-80. Picheansoonthon C, Koonterm S (2008) Three new species of the yellow-flowered Caulokaempferia (Zingiberaceae) from Northeastern Thailand. Taiwania 53(3): 248-257.

Picheansoonthon C, Mokkamul P (2006) A new species of Caulokaempferia (Zingiberaceae) from southern Laos. Natural History Bulletin of the Siam Society 54(1): 75-80.

Picheansoonthon C, Koonterm S, Chaiyoot A, Sukrong S, Homchuen S (2008) A new species of Caulokaempferia (Zingiberaceae) from Laos, with further information on other Caulokaempferia species from Laos. Natural History Bulletin of the Siam Society 56(1): 85-100.

Roy DK, Barbhuiya HA (2013) Taxonomy of Caulokaempferia (Zingiberaceae) in India. NeBio 4(6): 1-6.

Sangnark S, Prasarn S, Phokham B, Wongsuwan P, Picheansoonthon C (2016) The genus Caulokaempferia (Zingiberaceae) in Myanmar part 1: Two new species from south Myanmar. Shokubutsu Kenkyu Zasshi 91: 133-140.

IUCN (2017) Guidelines for using the IUCN red list categories and criteria. Version 13. Prepared by the Standards and Petitions Subcommittee. http://www.iucnredlist.org/documents/RedListGuidelines.pdf

Steudel ET (1841) Nomenclator Botanicus (Ed. 2, Vol. 2). Cotta, Stuttgart, 158 pp.

Suksathan P, Triboun P (2004) A new species of Caulokaempferia (Zingiberaceae) from Thailand. Edinburgh Journal of Botany 60(3): 513-516. https://doi.org/10.1017/ S0960428603000386 
Tiyaworanant S (2010) A new Caulokaempferia (Zingiberaceae) from Thailand. Telopea 12(4): 479-484. https://doi.org/10.7751/telopea20105838

Veldkamp JF (2016) The valid publication of Monolophus (Zingiberaceae) revisited. Gardens' Bulletin Singapore 68(1): 173-174. https://doi.org/10.3850/S2382581216000120

Wallich N (1820) Kaempferia secunda, Kaempferia linearis. In: Roxburgh W (Ed.) Flora Indica 1. Mission Press, Serampore, 19-20.

Wallich N (1832) A numerical list of dried specimens of plants in the East India Company's Museum, collected under the superintendence of Dr. Wallich, of the Company's Botanic Garden at Calcutta (the Wallich Catalogue). London, 6591-6593.

Wu TL, Chen SJ (1978) Materials for Chinese Zingiberaceae. Zhiwu Fenlei Xuebao 16(3): 25-46. 